\title{
Characterization of Solid Concrete Block Masonry
}

\author{
MUKESH KUMAR*
}

RECEIVED ON 22.06.2015 ACCEPTED ON 14.12.2015

\begin{abstract}
Masonry walls constituted of solid concrete blocks are used very commonly in the framed structures as well as in the load bearing structures in various parts of Pakistan. However, very limited understanding on the characteristics and behavior of this type of masonry walls, particularly from the perspective of the seismic design and assessment, is available. This paper attempts to investigate the important characteristics, such as strength and stiffness, of the walls constructed from two grades/types of these blocks, referred as Type- 1 and Type- 2 blocks. The dimensions of Type-1 and Type-2 blocks are

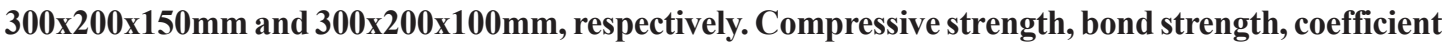
of friction, and diagonal (shear)strength of the masonry blocks and its assemblages are obtained from detailed experimental work. In the due course, the influence of the presence of the plaster on the masonry prisms made of two and three blocks subjected to compression and shear force respectively are investigated. The outcomes of the experimental investigation presented herein can be used effectively in macro and micro modelling of infill in framed structures as well as load bearing structures.
\end{abstract}

Key Words: Masonry Walls, Seismic Design and Assessment, Load Bearing Structures, Reinforced Concrete Structures, Mathematical Modelling.

\section{INTRODUCTION}

$\mathrm{C}$ C (Cement Concrete) blocks are used very frequently to construct infills in the framed structures and loading bearing walls in the nonengineered structures. In case of the framed structures, the presence of the infilled walls is generally ignored in the gravity as well as seismic design. However, the research has shown that the infills play a very important role to alter the stiffness and strength of the structure, the deflected shape of the structure and variation of the internal forces within the structure subjected to the lateral loads [1-3]. As a result, higher shear demands at the ends of beams and columns in contact with the part of the infill due to the strut mechanism can lead to shear failure of the elements. Furthermore, the presence of infill reduces the fundamental period of the structure resulting in higher shear demands. This in turn produces higher stresses on the members which are usually not designed to meet these demands. Moreover, infill panels at the floors other than the ground floor result in creating soft-storey which can subsequently lead to drift concentration and column hinging at both ends of the lower storey as well as cause shear failure of the ground floor columns. While most of

* Department of Earthquake Engineering, NED University of Engineering \& Technology, Karachi. 
the codes do not account for these effects, Eurocode 8 [4] stipulates provisions to avoid the detrimental effects of infill on the bounding frame. On the other hand, in our part of the world the non-engineered load bearing structures comprised of CC blocks are constructed based on the experience. These structures may be able to sustain the anticipated gravity load but are highly vulnerable in case of the seismic events.

The influence of the masonry infill walls is modeled using either a detailed finite element model [5] or simplified strut models [6-12]. Both these models require a large number of parameters in order to characterize the presence and influence of masonry infill walls. Furthermore, these parameters are region specific due to their dependence on the type of masonry infill employed in the RC (Reinforced Concrete) frames. Whilst a significant amount of work has been done in the other parts of the world on investigating the behavior of masonry walls [9,13-15], there is a scarcity of the research to study the behavior of infill walls which are made of CC blocks used very commonly in Pakistan.

Realizing the need for the research in this area, this paper attempts to investigate the masonry walls using two variations of the concrete blocks with different dimensions (geometry) and quality, referred hereafter as Type-1 and Type- 2 blocks. Type-1 blocks are $300 \mathrm{~mm}$ long, $200 \mathrm{~mm}$ wide and $150 \mathrm{~mm}$ thick, while Type-2 blocks are $300 \mathrm{~mm}$ long, $200 \mathrm{~mm}$ wide and $100 \mathrm{~mm}$ thick. While there are no standard procedures for construction of these blocks, roughly 1:5 ratio of cement to course sand by volume is used for Type-1 blocks and 1:3 ratio of cement to course sand by volume is used for Type-2 blocks, and equal volume of cement and water are used for both types of the blocks. Therefore, in relative terms, Type-1 blocks are expected to perform poorly in comparison to Type-2 blocks.
In the first stage of the experimental program, mechanical properties of solid concrete blocks and mortar are investigated under a compressive load. In the second stage, masonry assemblages are tested for the compressive strength, bond strength and coefficient of friction. Finally, the block masonry wallets are subjected to the diagonal loads to evaluate the compressive and shear strength of the walls. The characteristics of masonry obtained from the diagonal tests are used subsequently for macro modelling of infill to assess its effects on the strength and stiffness of a framed structure.

\section{EXPERIMENTAL INVESTIGATIONS}

\subsection{Compressive Strength of Masonry Units}

The masonry units comprising of the blocks and mortar are tested to obtain the average compressive strength and associated variability. In this regard, five blocks are tested for each type with displacement controlled UTM (Universal Testing Machine). The compressive load is applied on the area of $150 \times 300 \mathrm{~mm}$ for Type- 1 blocks and 100x300 mm for Type-2 blocks, as shown in Fig. 1(a-c). Compressive strengths of the tested blocks for both types are provided in Figs. 2-3; while the average strength, standard deviation and coefficient of variation are provided in Table 1. The average compressive strength of Type- 1 and Type-2 blocks is found to be 3.3 and 4.7 $\mathrm{MPa}$. As anticipated, the compressive strength of Type-1 blocks is significantly lower than Type-2 blocks. A total of 5 mortar cubes with dimension of $50 \mathrm{~mm}$ each side were prepared with 1:3 (cement: sand) ratio by volume with water cement ratio of 0.9 by volume and tested for the compressive strength at 28 days (Fig. 1). The sand used in the mortar consists of median grain size of $0.42 \mathrm{~mm}$, while maximum and minimum grain sizes are noted to be 9.5 and $0.075 \mathrm{~mm}$. The analysis shows that the sand can be classified as poorly graded. It needs to be noted that the composition of the mortar and the water cement ratio

Mehran University Research Journal of Engineering \& Technology, Volume 36, No. 1, January, 2017 [p-ISSN: 0254-7821, e-ISSN: 2413-7219] 
are selected based on the prevalent practice in the construction of masonry infills in low-rise RC structures. As a result, the water cement ratio is different from that

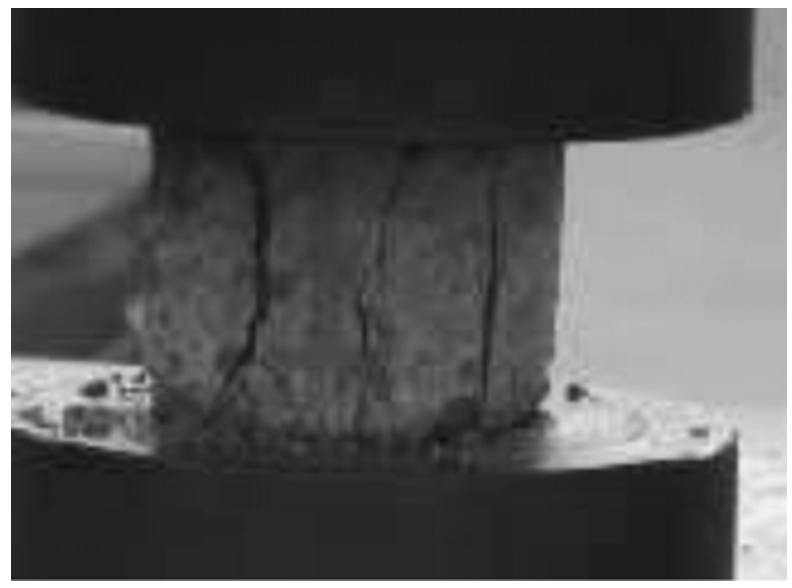

(a) MORTAR CUBE

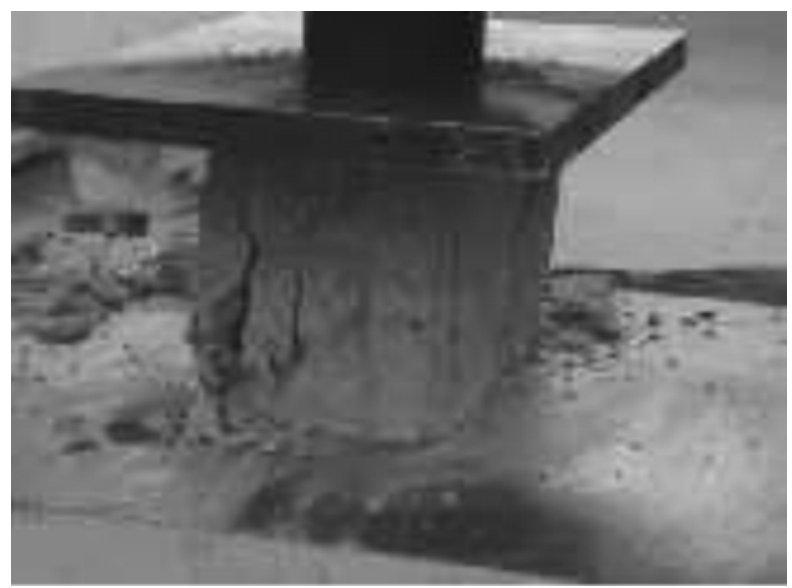

(b) BLOCK TYPE-1

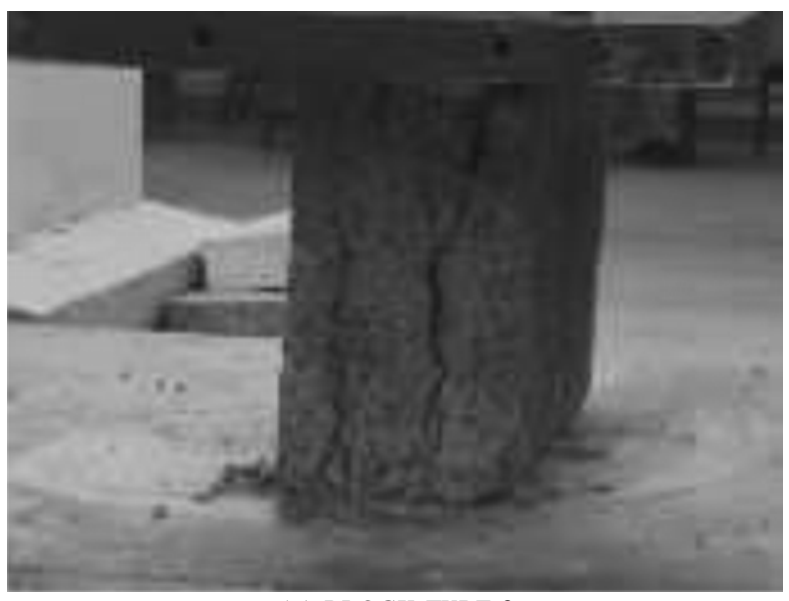

(c) BLOCK TYPE-2

FIG. 1. COMPRESSION TESTING specified in the codified provisions. The compressive strength for each specimen is shown in Fig. 4, while the statistical measures are reported in Table 1 . The average compressive strength of the mortar used in the study is found to be $6.73 \mathrm{MPa}$ with standard deviation of 0.75 MPa. The coefficient of variation of the compressive strengths of the blocks and mortar cubes ranges between 0.11 and 0.16 , thereby suggesting lesser variation of the strengths.

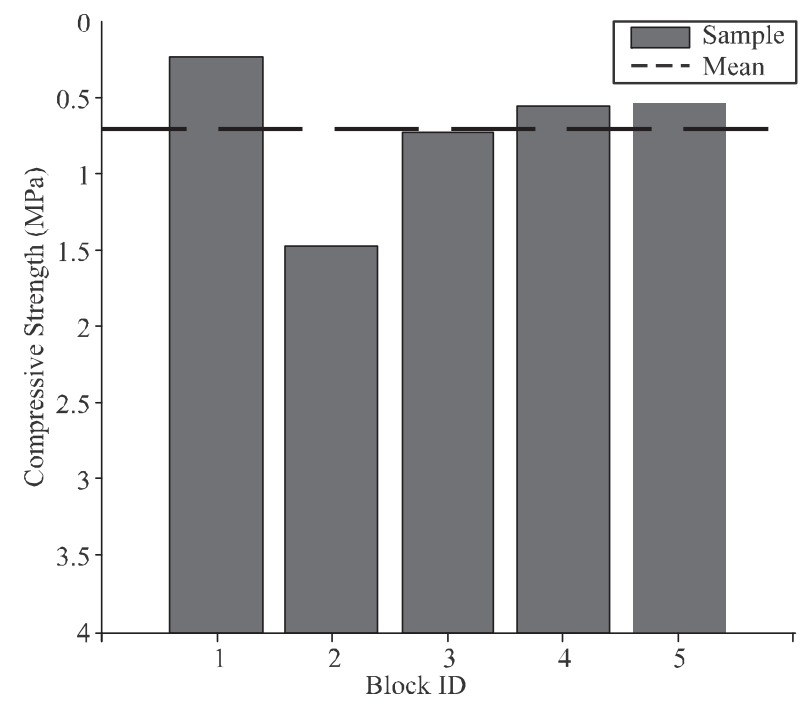

FIG. 2. COMPRESSIVE STRENGTHS OF TYPE-1 BLOCKS

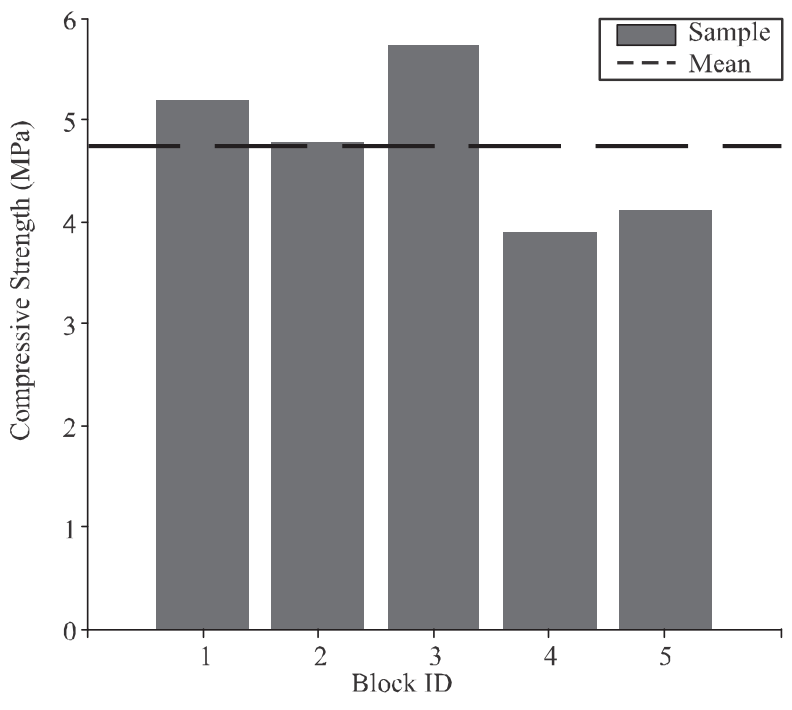

FIG. 3. COMPRESSIVE STRENGTHS OF TYPE-2 BLOCKS

Mehran University Research Journal of Engineering \& Technology, Volume 36, No. 1, January, 2017 [p-ISSN: 0254-7821, e-ISSN: 2413-7219] 


\subsection{Compressive Strength of Masonry Prisms}

Masonry prisms are constructed by joining two blocks with mortar (1/2" thick) on 200x300 mm face of the blocks, as shown in Fig. 5(a-d). In total twenty specimens are constructed with ten prisms each for Type- 1 and Type2 blocks. Each batch of ten specimens consisted of 5 prisms without plaster and 5 prisms with plaster on the remaining faces of the blocks to investigate the influence of plaster on the compressive strength of the masonry prisms. A correction factor of 0.86 is applied to account for the absence of gapping material as per ASTM C131403b [16]. The compressive strengths for twenty specimens at 28 days are provided in Figs. 6-7; the relevant statistics are provided in Table 2 . It is noted

TABLE 1. STATISTICS OF THE COMPRESSIVE STRENGTHSOF BLOCKS AND MORTAR

\begin{tabular}{|c|c|c|c|}
\hline Type of Blocks & $\begin{array}{c}\text { Average } \\
(\mathrm{Mpa})\end{array}$ & $\begin{array}{c}\text { Standard } \\
\text { Deviation } \\
\text { (Mpa) }\end{array}$ & $\begin{array}{c}\text { Coefficient of } \\
\text { Variation }\end{array}$ \\
\hline Type-1 Blocks & 3.29 & 0.46 & 0.14 \\
\hline Type-2 Blocks & 4.7 & 0.76 & 0.16 \\
\hline Mortar Cubes & 6.73 & 0.75 & 0.11 \\
\hline
\end{tabular}

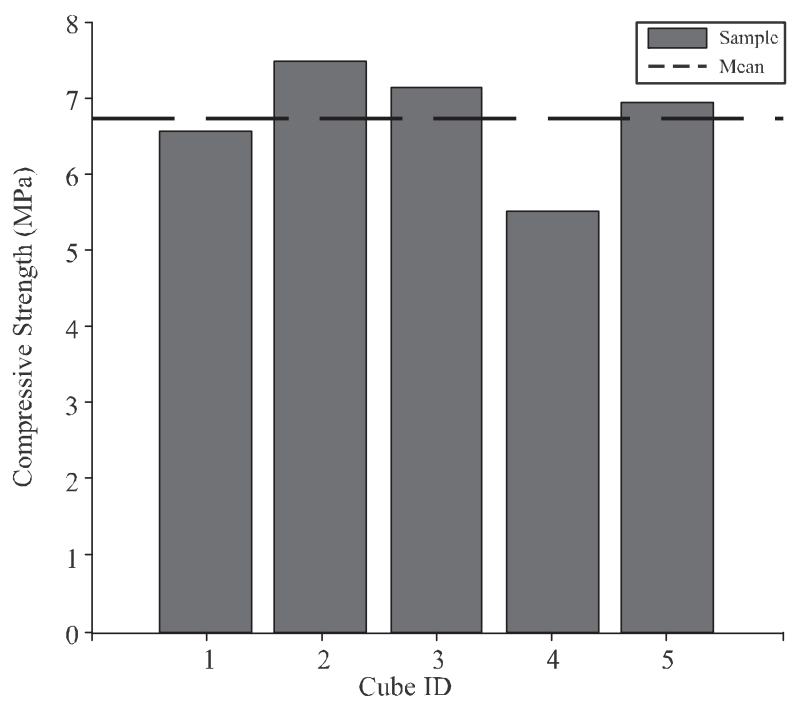

FIG. 4. COMPRESSIVE STRENGTHS OF MORTAR CUBES that the average compressive strength of the masonry prisms for Type-2 blocks without plaster is approximately four times greater than the average strength of Type-1 blocks. Furthermore, it is observed that the presence of the plaster enhances the compressive strength by 28 and $23 \%$ for prisms constructed from Type- 1 and Type2 blocks respectively. The coefficient of variation for all the cases is relatively low, thereby suggesting that the compressive strength of the prism is fairly consistent.

\section{BOND STRENGTH AND COEFFICIENT OF FRICTION OF MASONRYTRIPLETS}

Shear tests on the masonry triplets are conducted to evaluate the bond strength $\left(\tau_{\mathrm{o}}\right)$ and coefficient of friction $(\mu)$. The masonry triplets are constructed by joining three blocks side by side on 200x300 mm face of the blocks, as shown in Fig. 8(a-d). The force is applied on the central block to evaluate the bond strength of the triplets. Twenty masonry triplets are constructed, which comprise of ten prisms of Type-1 blocks and ten prisms of Type-2 blocks. Out of the ten prisms for each block type, five are plastered on all the sides whereas the remaining five are constructed without plaster. The bond strengths from the tests are provided in Figs. 9-10. It is calculated as the ratio of the maximum load resisted by a triplet sample to the loading area, when subjected to zero lateral force. The average bond strength of Type-1 triplets without plaster is found to be $0.12 \mathrm{MPa}$, which is approximately three times lower than Type-2 triplets without plaster; the other statistics are available in Table 3. Furthermore, it is noted that the influence of the presence of the plaster on the bond strength is very prominent for Type- 1 triplets and enhances the strength by $100 \%$. On the other hand, the influence of the presence of the plaster on the bond strength for Type-2 triplets is negligible. Overall, the coefficient of variation of the bond strength is relatively larger in comparison to the other tests discussed previously, hence indicating larger variability of the parameter.

Mehran University Research Journal of Engineering \& Technology, Volume 36, No. 1, January, 2017 [p-ISSN: 0254-7821, e-ISSN: 2413-7219] 
To evaluate the coefficient of friction, the masonry triplets are subjected to a lateral force (confinement force) as well as the normal force on the central block, as shown in Fig. 11(a-d). The lateral force on the sample between 25-40 kN was applied, using the work of Atkinson, et. al. [17] as reference. The influence of the confinement or lateral force can be visualized from the load versus displacement (stroke of the piston of the machine) curve provided fo two samples, one with confinement and the other without confinement, in Fig.

12. The coefficients of friction obtained from the tests are provided in Figs. 13-14, and the relevant statistics

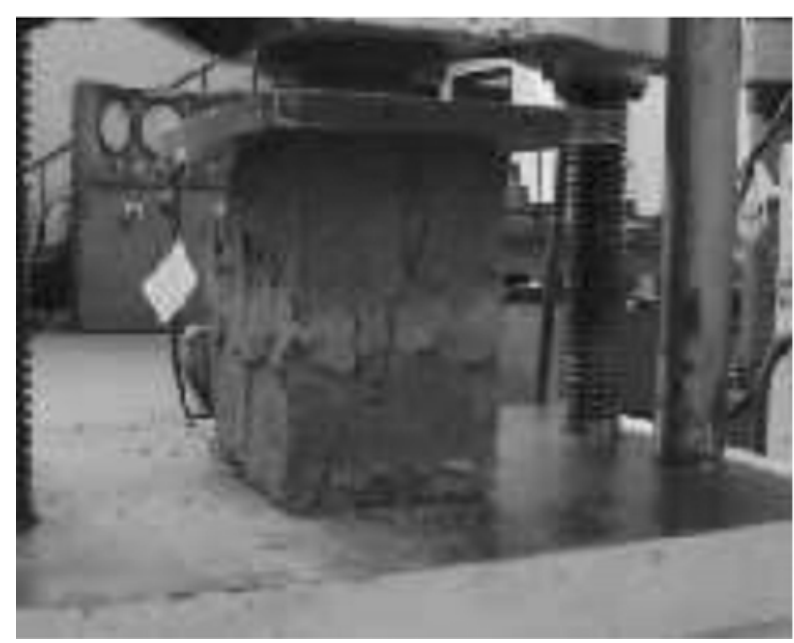

(a) TYPE-1, WITHOUT PLASTER

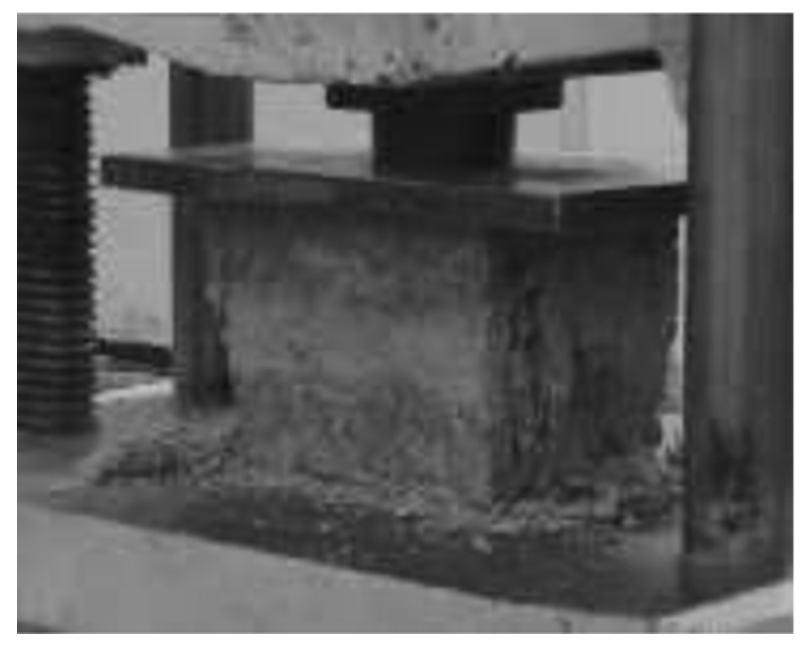

(c) TYPE-2, WITHOUT PLASTER are provided in Table 4 . It is noted that the average coefficient of friction ranges between 0.73 and 1.03. As anticipated, the coefficient of friction is least for Type1 triplets without plaster. As noted earlier for the bond strength, the coefficient of friction is affected significantly by the presence of plaster for Typetriplets. In contrast, the data suggests that the coefficient of friction for Type-2 triplets is reduced marginally by the presence of the plaster on the triplets. The coefficient of variation for the parameter ranges between 0.16 and 0.21 .

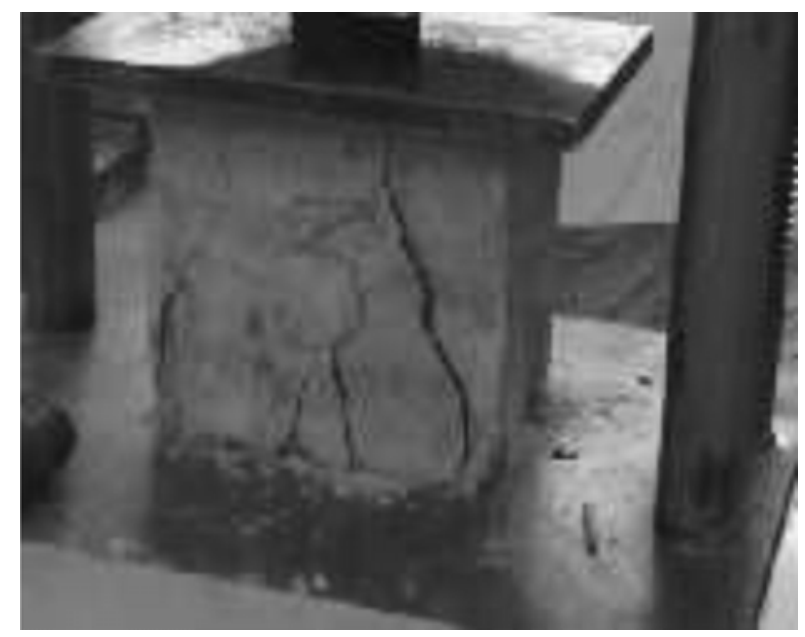

(b) TYPE-1, WITH PLASTER

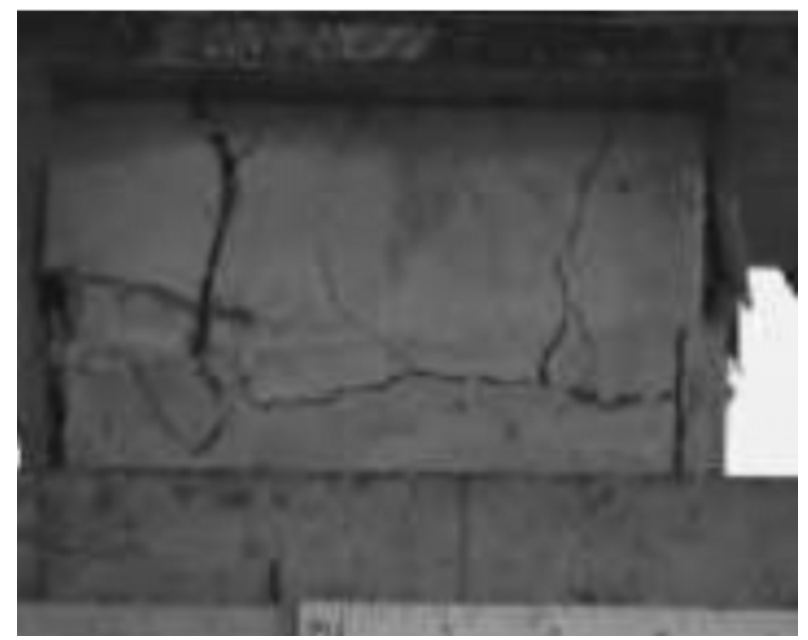

(d) TYPE-2, WITH PLASTER

FIG. 5. COMPRESSION TESTING OF MASONRY PRISMS

Mehran University Research Journal of Engineering \& Technology, Volume 36, No. 1, January, 2017 [p-ISSN: 0254-7821, e-ISSN: 2413-7219] 


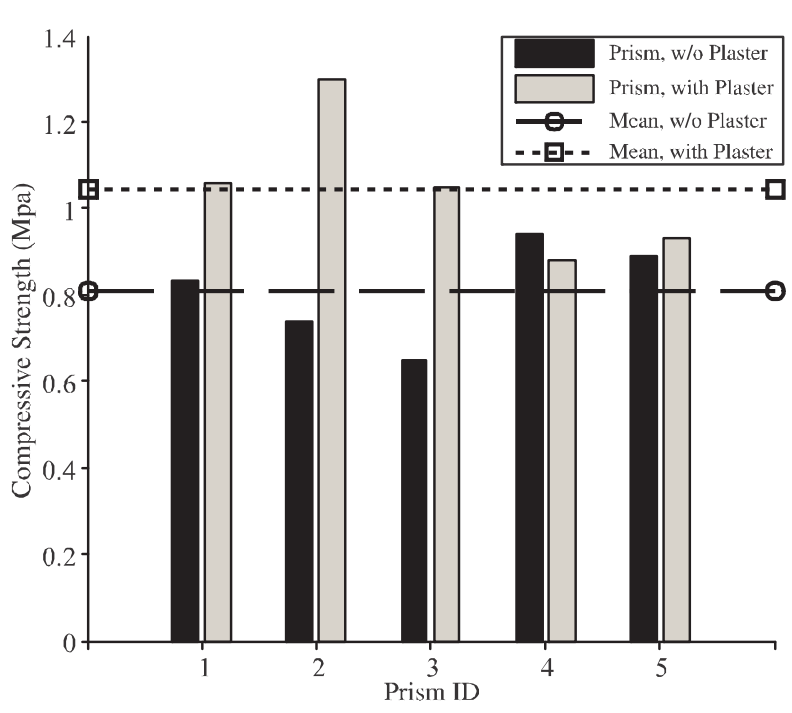

FIG. 6. COMPRESSIVE STRENGTHS OF MASONRY PRISMS OF TYPE-1 BLOCKS

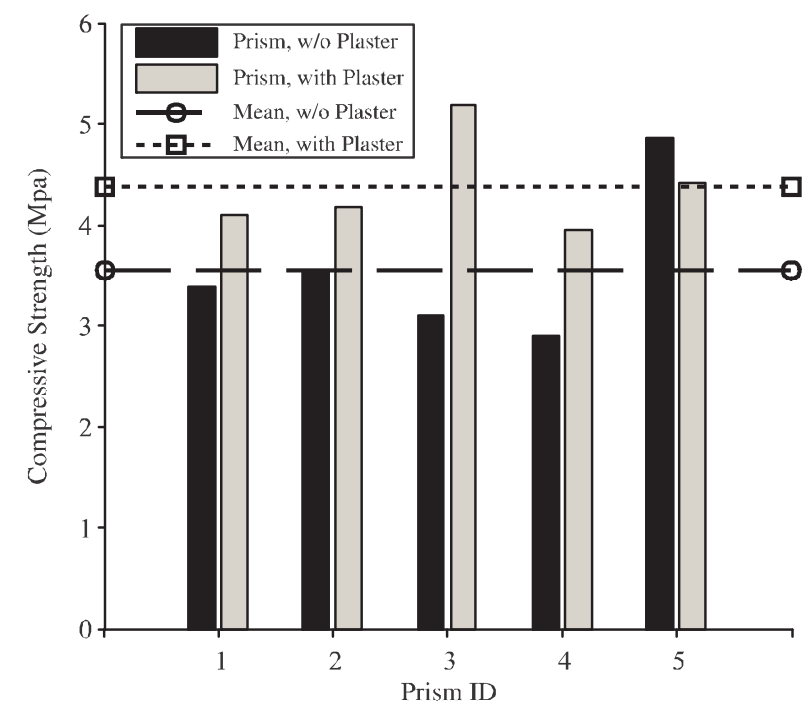

FIG. 7. COMPRESSIVE STRENGTHS OF MASONRY PRISMS OF TYPE-2 BLOCKS

TABLE 2. STATISTICS OF THE COMPRESSIVE STRENGTHS OF MASONRY PRISMS

\begin{tabular}{|c|c|c|c|}
\hline Type of Plasters & $\begin{array}{c}\text { Average } \\
\text { (Mpa) }\end{array}$ & $\begin{array}{c}\text { Standard } \\
\text { Deviation } \\
\text { (Mpa) }\end{array}$ & $\begin{array}{c}\text { Coefficient of } \\
\text { Variation }\end{array}$ \\
\hline Type-1, without Plaster & 0.81 & 0.12 & 0.14 \\
\hline Type-1, with Plaster & 1.04 & 0.16 & 0.16 \\
\hline Type-2, without Plaster & 3.56 & 0.77 & 0.22 \\
\hline Type-2, with Plaster & 4.37 & 0.49 & 0.11 \\
\hline
\end{tabular}

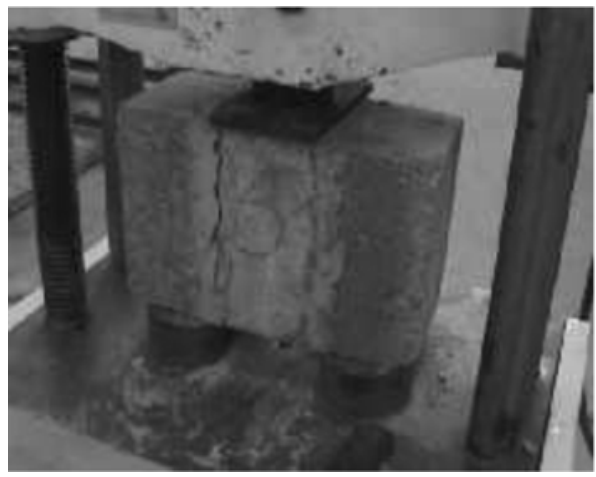

(a) TYPE-1, WITHOUT PLASTER

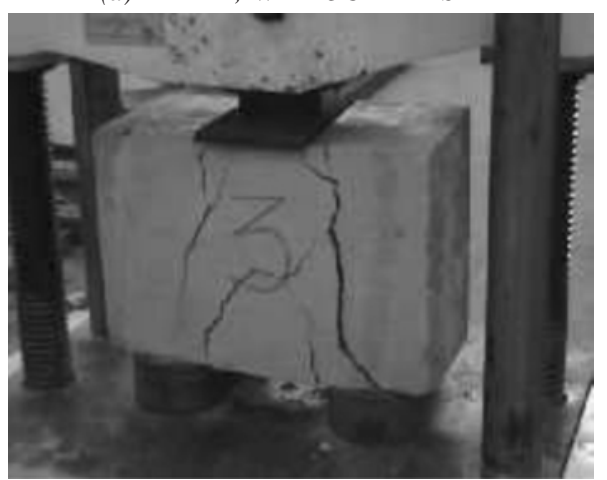

(b) TYPE-1, WITH PLASTER

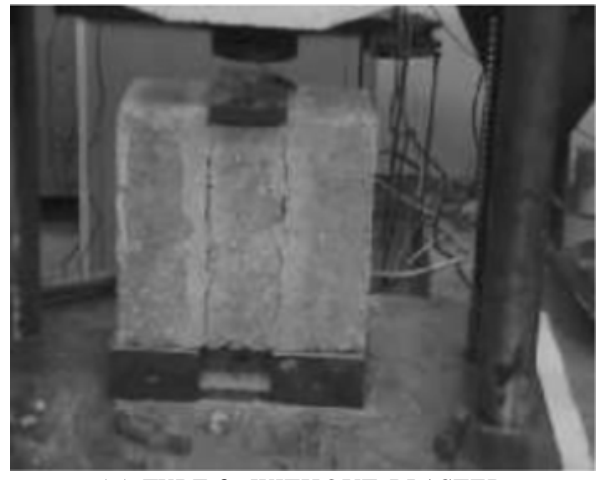

(c) TYPE-2, WITHOUT PLASTER

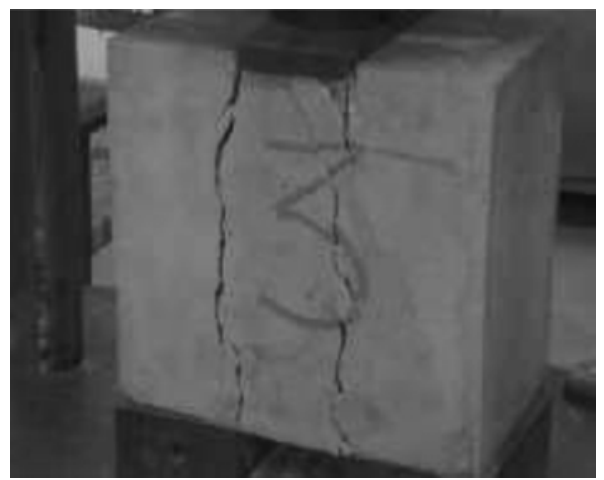

(d) TYPE-2, WITH PLASTER

FIG. 8. SHEAR TESTING OF MASONRY TRIPLETS WITH ZERO LATERAL FORCE

Mehran University Research Journal of Engineering \& Technology, Volume 36, No. 1, January, 2017 [p-ISSN: 0254-7821, e-ISSN: 2413-7219] 


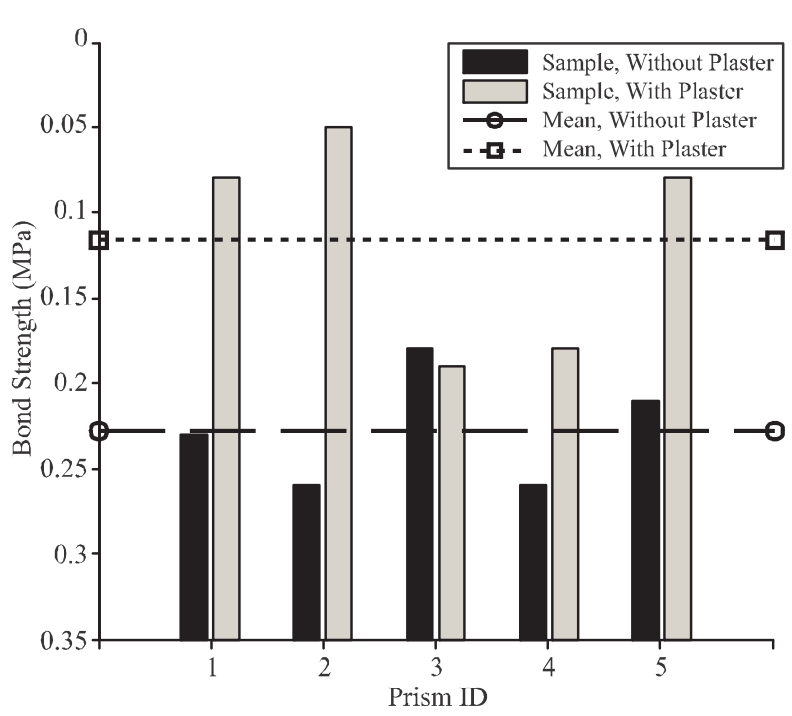

FIG. 9. BOND STRENGTHS OF MASONRY TRIPLETS OF TYPE-1 BLOCKS, WITH AND WITHOUT PLASTER

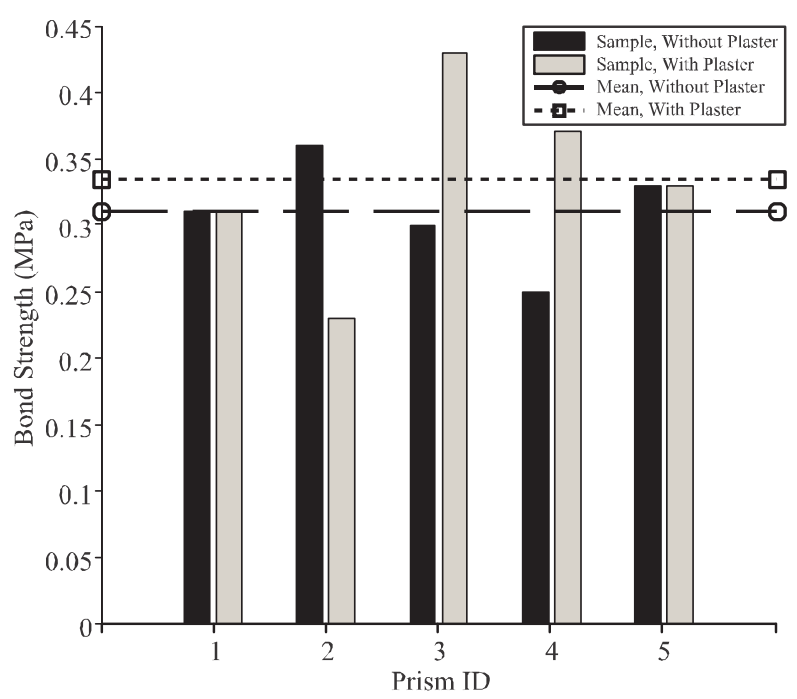

FIG. 10. BOND STRENGTHS OF MASONRY TRIPLETS OF TYPE-2 BLOCKS, WITH AND WITHOUT PLASTER

TABLE 3. STATISTICS OF THE BOND STRENGTHS OF MASONRY PRISMS

\begin{tabular}{|c|c|c|c|}
\hline Type of Plasters & $\begin{array}{c}\text { Average } \\
\text { (Mpa) }\end{array}$ & $\begin{array}{c}\text { Standard } \\
\text { Deviation } \\
\text { (Mpa) }\end{array}$ & $\begin{array}{c}\text { Coefficient of } \\
\text { Variation }\end{array}$ \\
\hline Type-1, without Plaster & 0.12 & 0.04 & 0.30 \\
\hline Type-1, with Plaster & 0.24 & 0.07 & 0.28 \\
\hline Type-2, without Plaster & 0.31 & 0.04 & 0.13 \\
\hline Type-2, with Plaster & 0.33 & 0.07 & 0.22 \\
\hline
\end{tabular}

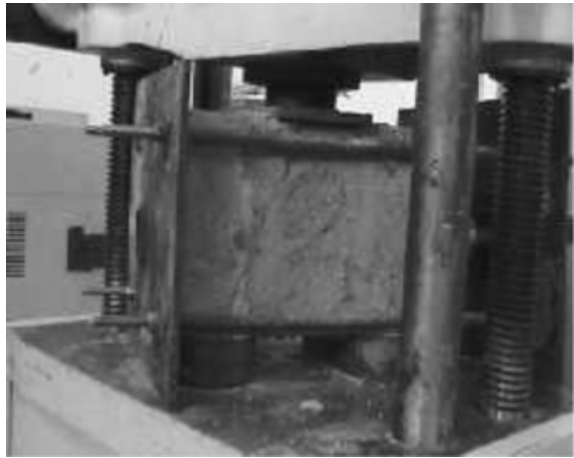

(a) TYPE-1, WITHOUT PLASTER

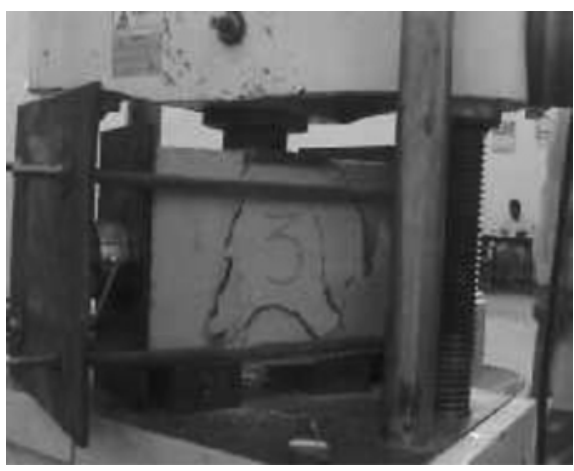

(b) TYPE-1, WITH PLASTER

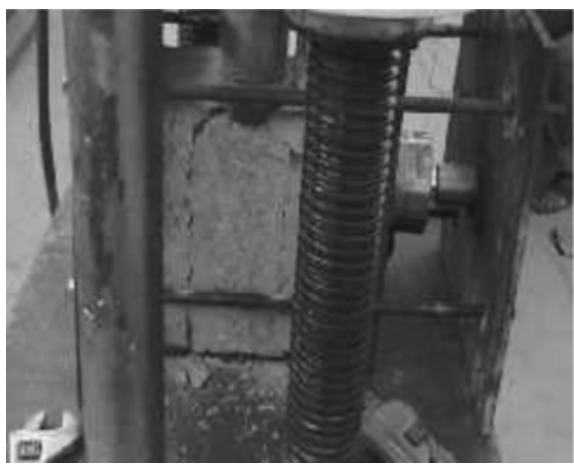

(c) TYPE-2, WITHOUT PLASTER

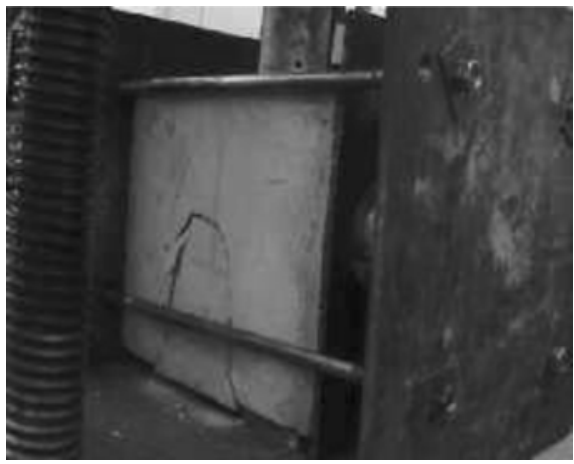

(d) TYPE-2, WITH PLASTER

FIG. 11. SHEAR TESTING OF MASONRY TRIPLETS WITH LATERAL FORCE

Mehran University Research Journal of Engineering \& Technology, Volume 36, No. 1, January, 2017 [p-ISSN: 0254-7821, e-ISSN: 2413-7219] 


\section{DIAGONAL SHEAR AND COMPRESSIVE STRENGTH OF MASONRY WALLETS}

In case of the infilled RC frames the masonry wall is subjected to the diagonal loads, it is therefore important to evaluate the strength contribution of the masonry walls subjected to the diagonal loading. In this regard, diagonal compression tests are conducted on a square wallet of 1287.5x1287.5 $\mathrm{mm}$ as per ASTM E519-02 [18] guidelines.

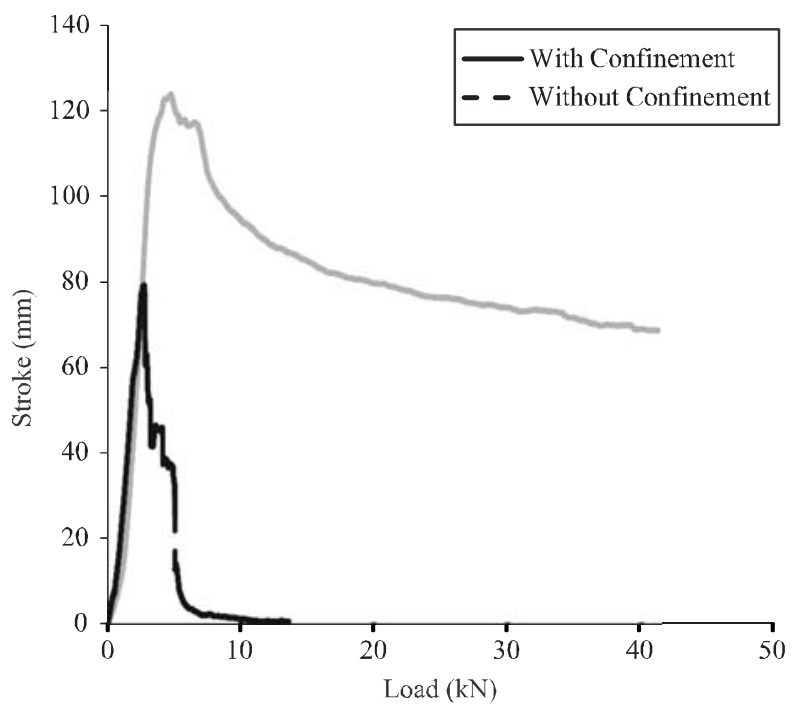

FIG. 12. LOAD DEFORMATION CURVE FOR THE SHEAR TEST OF A TRIPLET WITH PLASTER WITHOUT CONFINEMENT AND A TRIPLET WITH PLASTER WITH CONFINEMENT

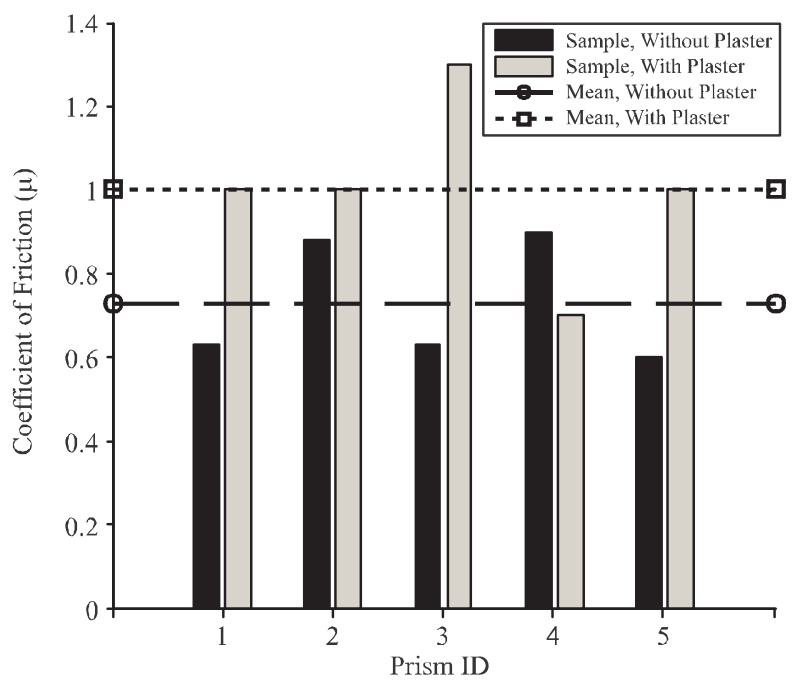

FIG. 13. OEFFICIENTS OF FRICTION OF TYPE-1 BLOCKS, WITH AND WITHOUT PLASTER
As shown in Fig. 15, a pit is prepared to accommodate the standard size of the wallets. Two steel assemblies were required to apply the diagonal load as per ASTM E519-02 [18] requirements. Four string pots are placed on the wallet, two along the diagonal parallel to the direction of the loading and the remaining in the diagonal perpendicular to the direction of loading at a spacing of $1 \mathrm{~m}$. The relative displacement divided by the spacing between the string pots provides the strain in the given direction. Two masonry wallets are tested at 28 days; Wall-1 is constructed with Type- 1 blocks with plaster on all sides of the panel whereas Wall-2 is constructed with Type- 2 blocks with plaster on all sides. The observations for each wallet are discussed below.

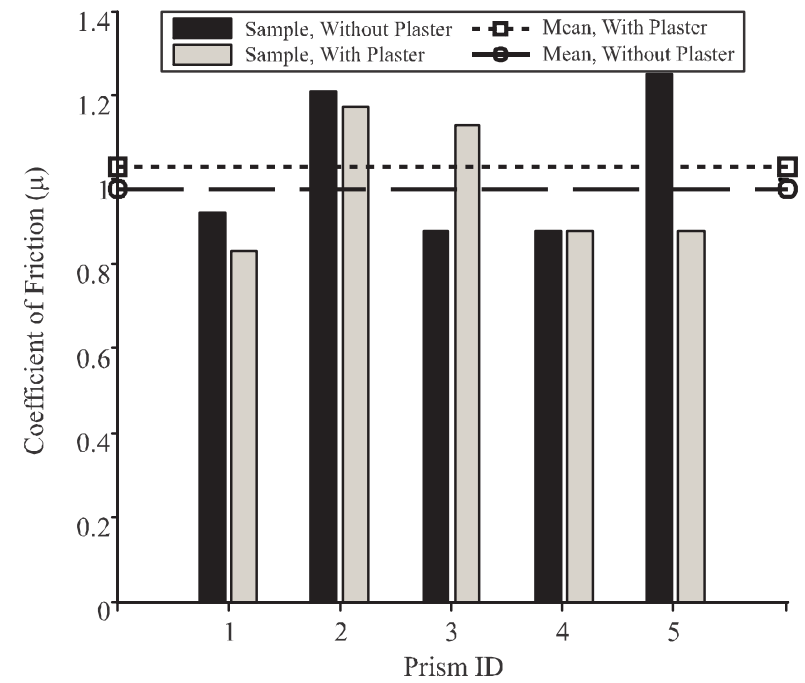

FIG. 14. COEFFICIENTS OF FRICTION OF TYPE-2 BLOCKS, WITH AND WITHOUT PLASTER

TABLE 4. STATISTICS OF THE COEFFICIENT OF FRICTION OF MASONRY PRISMS

\begin{tabular}{|c|c|c|c|}
\hline Type of Plasters & $\begin{array}{c}\text { Average } \\
\text { (Mpa) }\end{array}$ & $\begin{array}{c}\text { Standard } \\
\text { Deviation } \\
\text { (Mpa) }\end{array}$ & $\begin{array}{c}\text { Coefficient of } \\
\text { Variation }\end{array}$ \\
\hline Type-1, without Plaster & 0.73 & 0.15 & 0.21 \\
\hline Type-1, with Plaster & 1.00 & 0.21 & 0.21 \\
\hline Type-2, without Plaster & 1.03 & 0.19 & 0.18 \\
\hline Type-2, with Plaster & 0.98 & 0.16 & 0.16 \\
\hline
\end{tabular}

Mehran University Research Journal of Engineering \& Technology, Volume 36, No. 1, January, 2017 [p-ISSN: 0254-7821, e-ISSN: 2413-7219] 
On application of the vertical load on the first specimen (Wall-1), the wall cracked in the direction parallel to the applied loading as the crack propagated through the blocks as well as the mortar. The failure can be referred as a tension failure, which caused the panel to break into two pieces, as shown in Fig. 16. The maximum load at the time of failure for the first wallet was noted to be $102 \mathrm{kN}$. The compressive strength of the wallet is obtained by dividing the maximum load by the loading area of the loading showing shoe i.e. width of the loading shoe (254

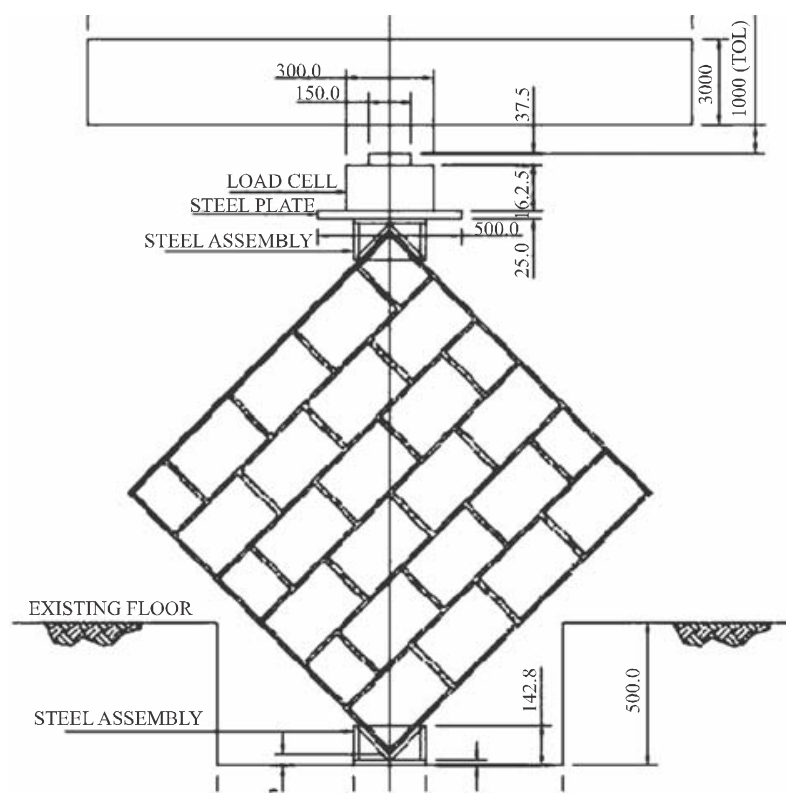

FIG. 15. SCHEMATIC DIAGRAM OF DIAGONAL COMPRESSION TEST SETUP SHOWING TOP \& BOTTOM ASSEMBLY WITH LOAD CELL $\mathrm{mm}$ ) multiplied by the thickness of the masonry wallet $(175 \mathrm{~mm})$, whereas the shear strength of the panel is calculated using the expressions provided in ASTM E51902 [18] provisions, also provided in Equation (1):

$$
S_{s}=\frac{0.70 \pi}{A_{n}}
$$

In Equation (1) $\mathrm{S}_{\mathrm{s}}$ is the shear stress on net area; $\mathrm{P}$ is the applied load; and $A_{n}$ is the net area of the specimen, calculated as follows:

$A_{n}=\left(\frac{w+h}{2}\right) t n$

In Equation (2), w represents width of specimen; $h$ represents the height of specimen; $t$ is the total thickness of specimen; and $\mathrm{n}$ is the percent of the gross area of the unit that is solid.

The compressive and shear strengths of the wallet are found to be 2.565 and $0.498 \mathrm{MPa}$ respectively. The longitudinal and transverse strains at the failure are recorded as 0.0043 and 0.0013 respectively.

In case of the second wallet (Wall-2), on application of the diagonal load the wall failed along the masonry joints whereas the blocks did not crack at all and the failure
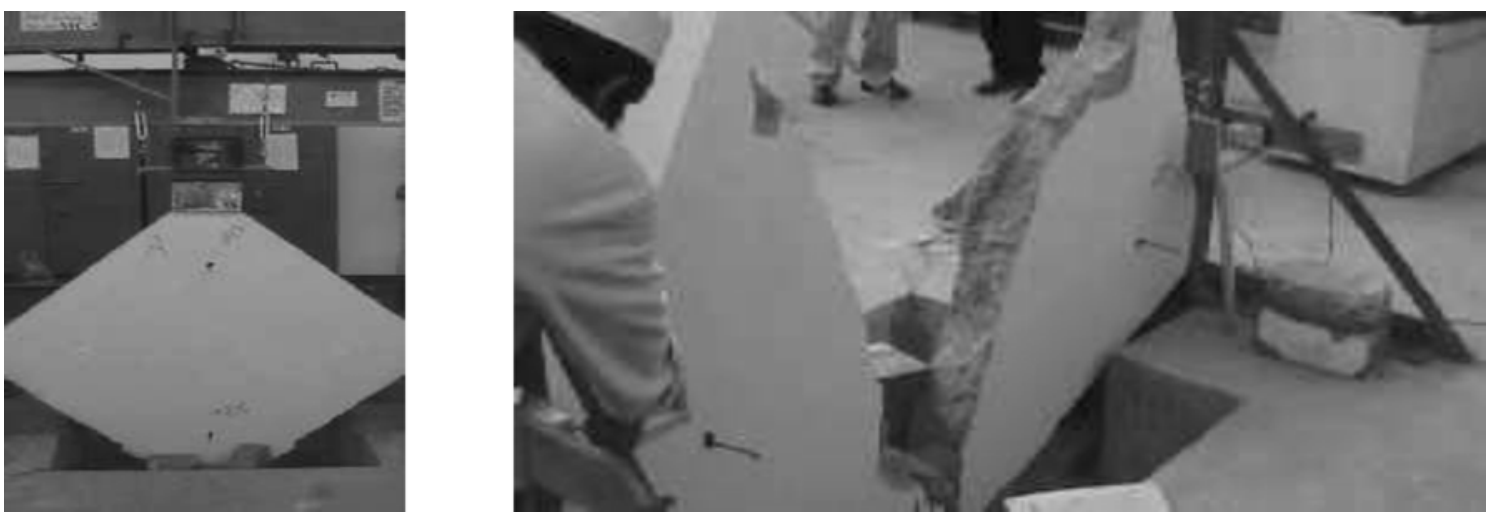

FIG. 16. PHOTOS SHOWING THE DIAGONAL COMPRESSION TESTING OF WALL-1 AT 28 DAYS

Mehran University Research Journal of Engineering \& Technology, Volume 36, No. 1, January, 2017 [p-ISSN: 0254-7821, e-ISSN: 2413-7219] 
type can be classified as shear failure along the mortar joints, as shown in Fig. 17. The possible reason for the failure type is due to higher strength of the blocks in comparison to the mortar joints. The failure occurred suddenly when the load reached a value of $139 \mathrm{kN}$. Adopting the same procedure defined previously, the compressive and shear strengths of the wallets are found to be 2.96 and $0.575 \mathrm{MPa}$ respectively. In this case, the longitudinal and transverse strains were reported to be 0.0018 and 0.0084 respectively.

The experimental data shows that the masonry wallet made of Type-2 blocks is significantly stronger than that of Type-1 blocks due to relatively higher strength of Type2 blocks. Moreover, it is clearly shown that the strength of the blocks completely alters the failure type of the masonry wallets subjected to the diagonal loads. Using the compressive strength and corresponding strains in the longitudinal direction the secant stiffness of Wall-1 and Wall-2 are found to be 596 and $1644 \mathrm{MPa}$.

\section{INFLUENCE OF INFILL ON NONLINEAR RESPONSE OF RC FRAMES}

The parameters obtained from the tests presented above are employed to investigate the influence of both infill types on the strength and stiffness of RC frames. To this end, mathematical models of a two storey single bay frame and a four storey single bay frame, both with center line to center line width of $2.7 \times 2.7 \mathrm{~m}$ and clear height of $2.1 \mathrm{~m}$ are developed in SeismoStruct [19] for three scenarios, namely: (i) bare frame without infill; (ii) infilled frame with Type-1 wall and (iii) infilled frame with Type-2 wall. Reinforcement of three $12 \mathrm{~mm}$ diameter bars are provided at the top and bottom of the beam with cross section of $150 \times 600 \mathrm{~mm}$, while the columns of $300 \times 300 \mathrm{~mm}$ cross section are reinforced with four $20 \mathrm{~mm}$ diameters bars at each corner of the column. Concrete is modelled using uniaxial constant confinement model [20] using the compressive strength of concrete as $3 \mathrm{ksi}$, while steel is modelled using a bilinear stress-strain model with the yield strength of 60 ksi. As discussed earlier, the infill bounded by RC frames can be modelled either using micro models or macro models. In the parametric study presented herein the infill panels are modelled using six-strut model developed by [9] is adopted. In the model, two parallel struts are available in the diagonal direction to carry the axial loads, whereas two shear struts are available to transfer the shear from the top to the bottom of the panel. Separate hysteresis rules are available in the model for both types of struts. The average values of the diagonal compressive strength, bond strength and coefficient of friction are acquired from the experimental work presented earlier, while the default values of the other parameters are
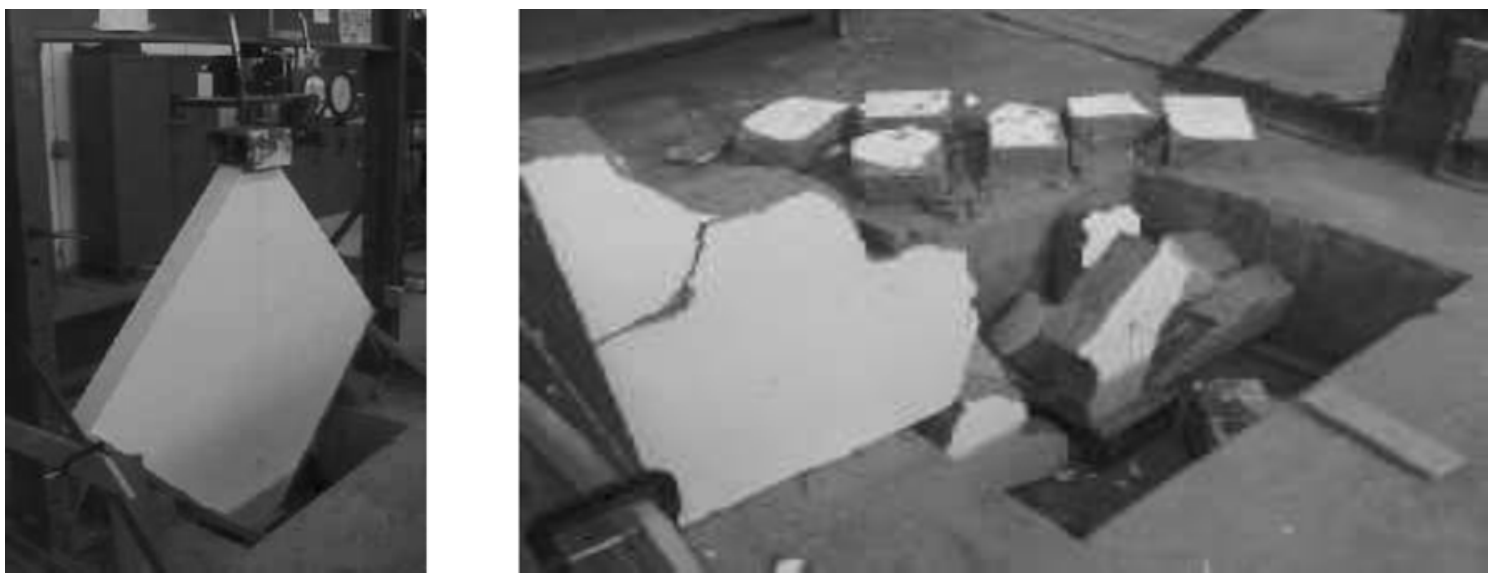

FIG. 17. PHOTOS SHOWING THE DIAGONAL COMPRESSION TESTING OF WALL-2 AT 28 DAYS

Mehran University Research Journal of Engineering \& Technology, Volume 36, No. 1, January, 2017 [p-ISSN: 0254-7821, e-ISSN: 2413-7219] 
adopted. Displacement controlled pushover analysis with displacement increment of $1 \mathrm{~mm}$ is carried out until the interstorey drift ratio in any of the storeys for a given frame reaches $2.5 \%$. The limit of $2-2.5 \%$ is generally specified in various code provisions such as UBC-97 [21].

The pushover curves for the two storey frame representing three scenarios are presented in Fig. 18. It may be observed that the presence of the infill changes the response of the RC frame significantly. In terms of strength, the presence of infill increases the strength of RC frame roughly by $50 \%$, which also means higher shear demands on the components of the frame. It is interesting to note that the change of infill type does not affect the results noticeably. For the bare frame, the yielding of the reinforcement is initiated at the ends of the first storey beam followed by yielding at the bottom of the ground floor columns. Expectedly, the yielding of the reinforcement at the ends of the second floor occurs afterwards. For the infilled frames with Type-1 and Type-2, the sequence of the yielding of reinforcement is identical to that of the bare frame. In addition, the interstorey drift ratios of the frames for the instants when the first yield and maximum base shear occur are noted for all the frames to investigate the influence of the infill panels on the displacement profile of the frames. The interstorey drift ratios at a given instant for a frame are divided with the interstorey drift ratio of the top storey to obtain NIDRA (Normalized Interstorey Drift Ratio). The normalized interstorey drift ratios for three versions of the two storey frames at the first yield and maximum base shear are provided in Figs. 19-20. For the two storey frames it is noted that at the occurrence of the first yield the interstorey drift at the top storey is greater than the bottom storey for all three scenarios. For the bare frame the drift profile remains same at the occurrence of the maximum shear, whereas for the infilled frames the drift at the bottom storey increases in comparison to the top storey forming a linear displacement profile.

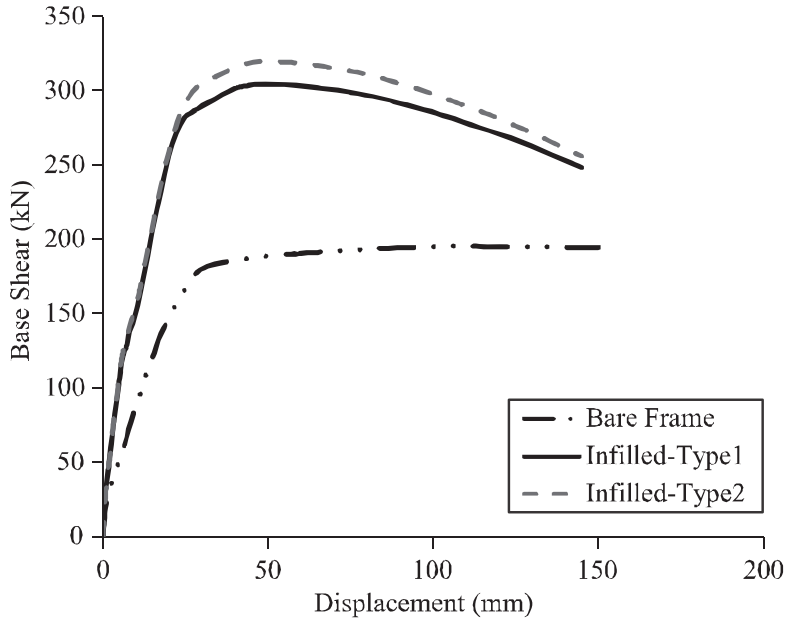

FIG. 18. PUSHOVER CURVE OF THE TWO STOREYED RC FRAMES MODELLED FOR THREE SCENARIOS NAMELY I) BARE FRAME WITHOUT INFILL; II) INFILLED FRAME WITH TYPE-1 INFILL AND III) INFILLED FRAME WITH TYPE-2 INFILL

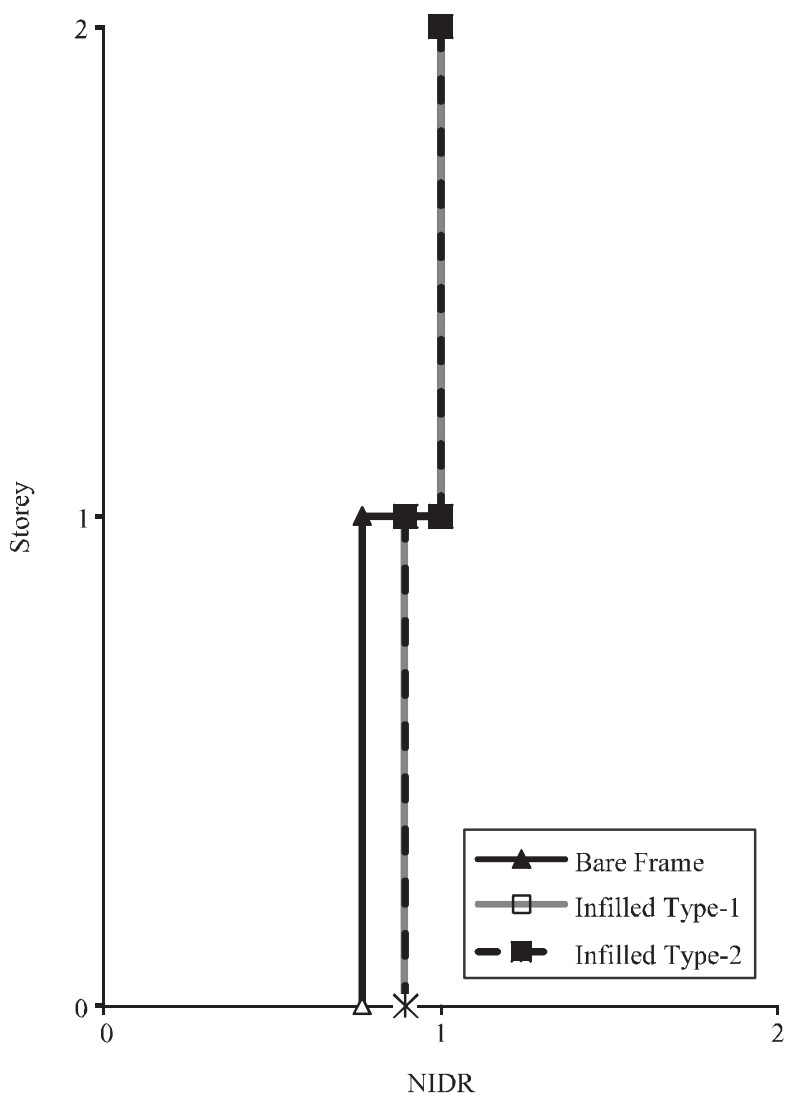

FIG. 19. NORMALIZED INTERSTOREY DRIFT RATIOS FOR THE TWO STOREYED FRAMES AT THE OCCURRENCE OF THE FIRST YIELD IN THE RESPECTIVE FRAMES

Mehran University Research Journal of Engineering \& Technology, Volume 36, No. 1, January, 2017 [p-ISSN: 0254-7821, e-ISSN: 2413-7219] 
For the four storey frames, the pushover curves are presented in Fig. 21. As noticed for the two storey frames, the strength of the four storey frames enhanced significantly with the presence of the infill panels. Moreover, the change of the infill types does not affect the results significantly. For the bare frame with four storeys, the yielding is first observed at the ends of the first storey beam followed by the yielding in the second and third storey beams. Subsequently, the yielding of the bottom of the ground storey columns is observed followed by the yielding at the ends of the fourth storey beam. On the other hand, in case of the four storeyed infilled frames, the yielding is noted on the ends of the first and second storeys followed by the yielding in the bottom of the ground storey columns. Yielding at the

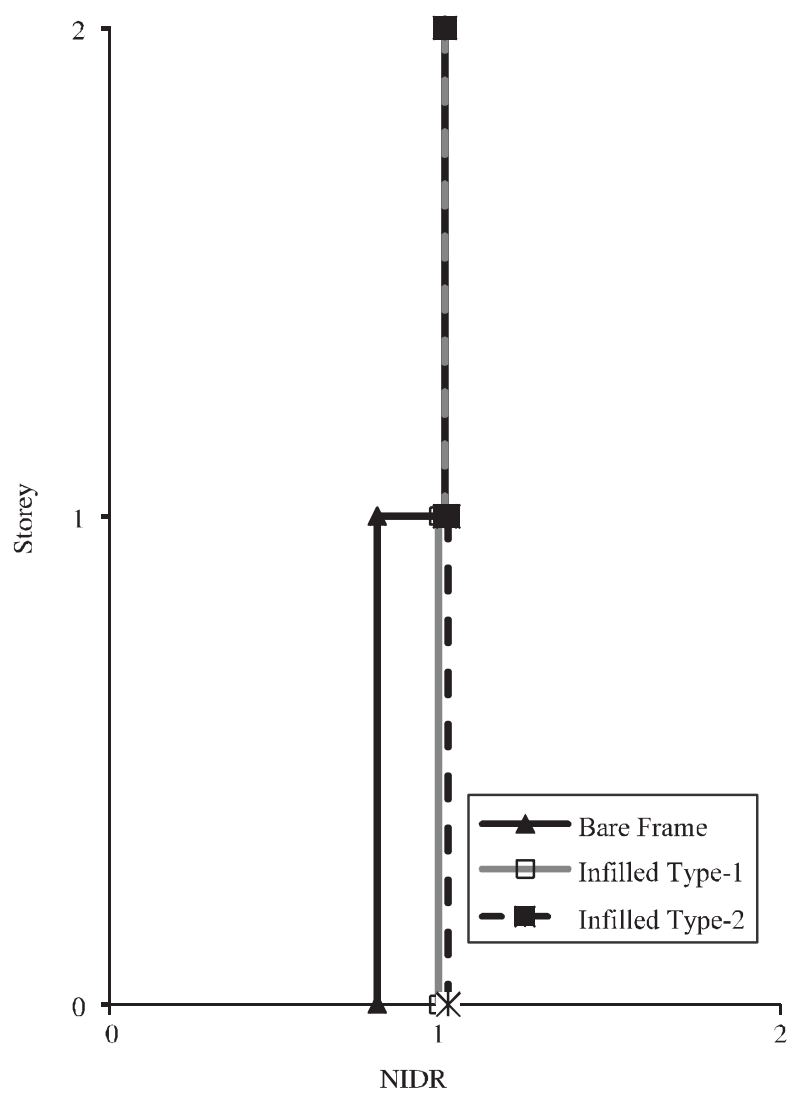

FIG. 20. NORMALIZED INTERSTOREY DRIFT RATIOS FOR THE TWO STOREYED FRAMES AT THE OCCURRENCE OF THE MAXIMUM BASE SHEAR IN THE RESPECTIVE FRAMES ends of the third storey beam is subsequently reported, while the fourth storey beam does not yield until the target interstorey drift ratio is reached. The normalized drift profiles are presented for the four storey frames at the occurrence of the first yield and the maximum base shear in Figs. 22-23. For the bare frame it is noted that the interstorey drifts at the second and third storey are larger than the remaining storeys, at the occurrence of the first yield. On the other hand, for the infilled frame, the drifts at the bottom three storeys are larger than the top storey. As noted earlier for the two storey frames, for the infilled frames, the drifts in the bottom storey tend to increase significantly at the occurrence of the maximum shear.

\section{CONCLUSION}

The characteristics of the masonry made of solid cement concrete blocks are explored in this work using two varieties of the blocks. It is noted that the average compressive strength of $150 \mathrm{~mm}$ thick blocks (Type-1) is found to be $3.29 \mathrm{MPa}$, which is approximately $42 \%$ lesser than the $100 \mathrm{~mm}$ thick blocks used in the study. It is noted that the average compressive strength of the

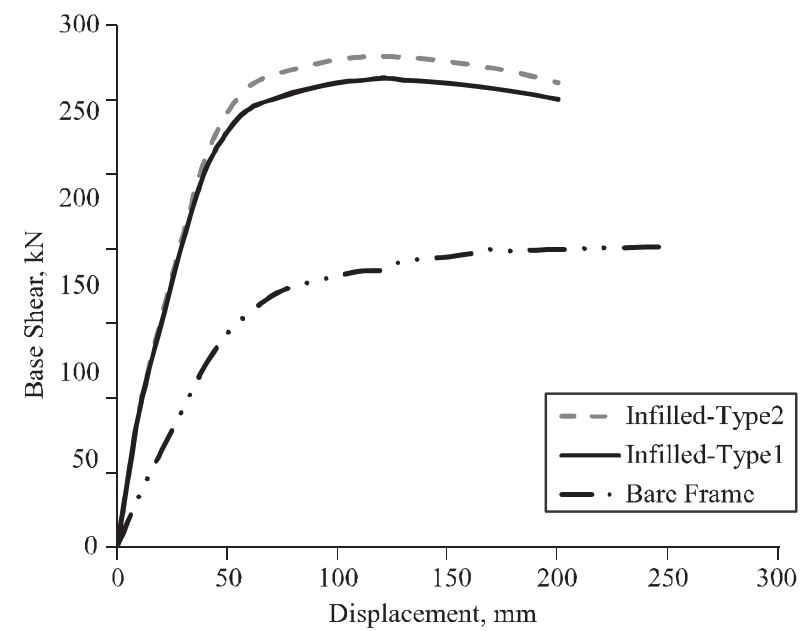

FIG. 21. PUSHOVER CURVE OF THE FOUR STOREYED RC FRAMES MODELLED FOR THREE SCENARIOS NAMELY I) BARE FRAME WITHOUT INFILL; II) INFILLED FRAME WITH TYPE-1 INFILL AND III) INFILLED FRAME WITH TYPE-2 INFILL

Mehran University Research Journal of Engineering \& Technology, Volume 36, No. 1, January, 2017 [p-ISSN: 0254-7821, e-ISSN: 2413-7219] 
masonry prisms is lower than the average compressive strengths blocks and mortar for both types of blocks. The bond strength of triplets subjected to shear is noted to be in the range of $0.12-0.33 \mathrm{MPa}$, while the coefficient of friction ranges between 0.73 and 1.03. In general, it is noted that the application of plaster has significant influence on the compressive strength, bond strength and coefficient of friction of Type-1 prisms and triplets. On the other hand, it is observed that the presence of plaster has negligible influence on the bond strength and coefficient of friction of Type-2 triplets, whereas it has reasonable influence on the compressive strength

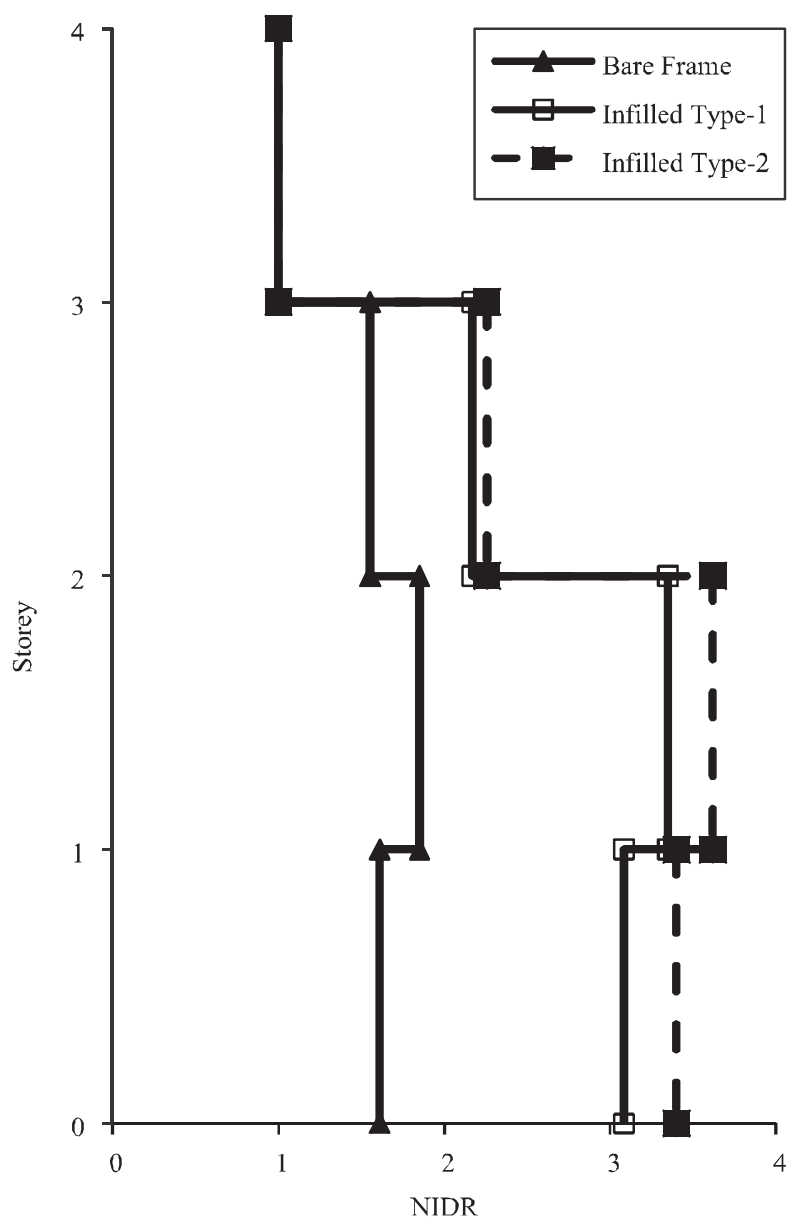

FIG. 22. NORMALIZED INTERSTOREY DRIFT RATIOS FOR THE FOUR STOREYED FRAMES AT THE OCCURRENCE OF THE FIRST YIELD IN THE RESPECTIVE FRAMES of Type-2 prisms. Finally, the diagonal compressive and shear strengths, obtained with the aid of diagonal compression test, for Wall-1 made of Type-1 blocks are found to be 2.565 and $0.498 \mathrm{MPa}$. It is noted that the presence of higher quality blocks in Wall-2 enhance the compressive and shear strengths by $15 \%$.

\section{ACKNOWLEDGEMENT}

Author would like to express our gratitude to NED University of Engineering \& Technology, Karachi, Pakistan, for providing the funding of the research through Rafeeqi Endowment Fund.

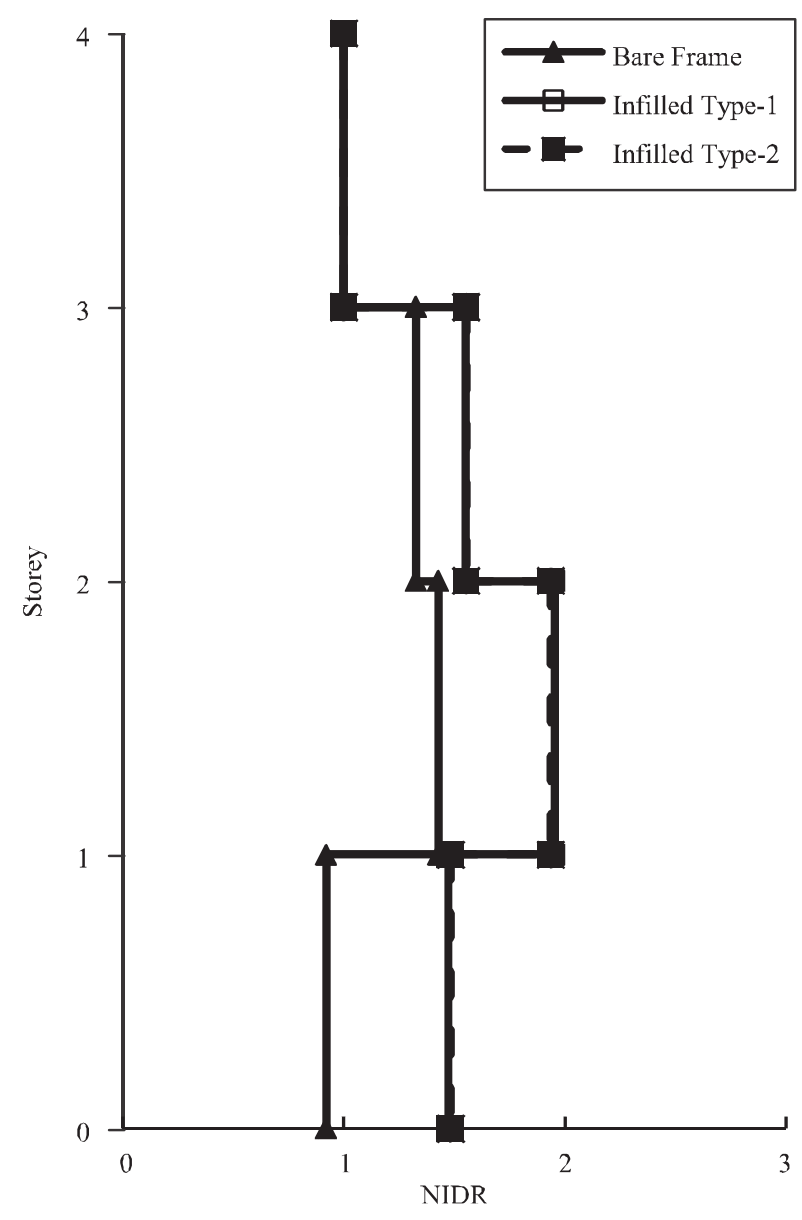

FIG. 23. NORMALIZED INTERSTOREY DRIFT RATIOS FOR THE FOUR STOREYED FRAMES AT THE OCCURRENCE OF THE MAXIMUM BASE SHEAR IN THE RESPECTIVE FRAMES

Mehran University Research Journal of Engineering \& Technology, Volume 36, No. 1, January, 2017 [p-ISSN: 0254-7821, e-ISSN: 2413-7219] 


\section{REFERENCES}

[1] Al-Chaar, G., Issa, M., and Sweeney, S., "Behavior of Masonry-Infilled Nonductile Reinforced Concrete Frames", Journal of Structural Engineering, Volume 128, No. 8, pp. 1055-1063, 2002.

Fardis, M., "Seismic Design Issues for Masonry-Infilled RC Frames", Proceedings of $1^{\text {st }}$ European Conference on Earthquake Engineering and Seismology, Paper 313, Geneva, Switzerland, 2006.

[3] Dorji, J.T., "Modelling of Infilled Frame Structures Under Seismic Loads", The Open Construction and Building Journal, Volume 3, pp. 119-129, 2009.

[4] CEN, "Eurocode 8 - Design of Structures for Earthquake Resistance - Part-1: General Rules, Seismic Actions and Rules for Buildings, Pr-EN 1998-1, Final Draft, December 2003", Comite Europeen de Normalisation, Brussels, 2004.

[5] Asteris, P.G., "Finite Element Micro-Modeling of Infilled Frames", Electronic Journal of Structural Engineering, Volume 8, No. 8, pp. 1-11, 2008.

[6] Smith, B.S., "Lateral Stiffness of Infilled Frames", Journal of Structure Division, Volume 88, No. 6, pp. 183-199, 1962.

[7] Holmes, M., "Combined Loading in Infilled Frames", Proceedings of Institute of Civil Engineering, Structure Buildings, Volume 25, No. 1, pp. 31-38, 1963.

Smith, B.S., and Carter, C., "A Method of Analysis for Infilled Frames", Proceedings of Institute of Civil Engineering, Volume 44, No. 1, pp. 31-48, 1969.

[9] Crisafulli, F.G., "Seismic Behavior of Reinforced Concrete Structures with Masonry Infills", Ph.D. Thesis, University of Canterbury, Christchurch, New Zealand, 1997.

[10] Madan, A., Reinhorn, A.M., Mander, J.B., and Valles, R.E., "Modeling of Masonry Infill Panels for Structural Analysis", Journal of Structural Engineering, Volume 123, No. 10, pp. 1295-1302, 1997.

[11] Asteris, P.G., Antoniou, S.T., Sophianopoulos, D.S., and Chrysostomou, C.Z., "Mathematical Macromodeling of Infilled Frames: State of the Art", Journal of Structural Engineering, Volume 137, No. 12, pp. 1508-1517, 2011.

[12] Smyrou, E., Blandon, C., Antoniou, S., Pinho, R., and Crisafulli, F., "Implementation and Verification of a Masonry Panel Model for Nonlinear Dynamic Analysis of Infilled RC Frames", Bulletin of Earthquake Engineering, Volume 9, No. 5, pp. 1519-1534, 2011.

[13] Hemant, B.K., Durgesh, C.R., and Sudhir, K.J., "StressStrain Characteristics of Clay Brick Masonry under Uniaxial Compression", Journal of Materials Civil Engineering, Volume19, No. 9, pp. 728-739, 2007.

[14] Bergami, A.B., "Implementation and Experimental Verification of Models for Non-Linear Analysis of Masonry In-Filled RC Frames", Ph.D. Thesis, Universitàdeglistudi ROMA TRE, 2007.

[15] Gumaste, K.S., Nanjunda Rao, K.S., Venkatarama Reddy, B.V., and Jagdish, K.S., "Strength and Elasticity of Brick Masonry Prism and Wallettes under Compression", Materials and Structures, Volume 40, pp. 241-253, 2007.

[16] ASTM., "Standard Test Method for Compressive Strength of Masonry Prisms", C1314-03b, ASTM International, Pennsylvania, United States, 2003.

[17] Atkinson, R.H., Amadei, B.P., Saeb, S., andSture, S., "Response of Masonry Bed Joints in Direct Shear", Journal of Structural Engineering, Volume 115, No. 9, pp. 2276-2296, 1989.

[18] ASTM., "Standard Test Method for Diagonal Tension (Shear) in Masonry Assemblages", E519-02, ASTM International, West Conshohocken, PA, USA, 2002.

[19] SeismoSoft, SeismoStruct, "SeismoStruct -A Computer Program for Static and Dynamic Nonlinear Analysis of Framed Structures", (Available Online from http:// www.seismosoft.com, 2006.

[20] Mander, J.B., Priestley, M.J., and Park, R., "Theoretical Stress-Strain Model for Confined Concrete", Journal of Structural Engineering, Volume 114, No. 8, pp. 1804-1826, 1988.

[21] Code, Uniform Building, "Structural Engineering Design Provisions", International Conference of Building Officials, Volume 2. 1997. 